\title{
Responsible investing in South Africa - drivers, barriers and enablers
}

\author{
S. Viviers* \\ Department of Business Management, Nelson Mandela Metropolitan University, \\ PO Box 77000, Port Elizabeth 6031, Republic of South Africa \\ suzette.viviers@nmmu.ac.za \\ N.S. Eccles \\ Noah Chair in Responsible Investment, Centre for Corporate Citizenship, \\ Unisa Main Campus, Preller Street, Tshwane 0003, Republic of South Africa \\ D. de Jongh \\ Centre for Corporate Citizenship, Unisa Main Campus, Preller Street, Tshwane 0003, Republic of South Africa \\ J.K. Bosch \\ Department of Business Management, Nelson Mandela Metropolitan University, \\ PO Box 77000, Port Elizabeth 6031, Republic of South Africa \\ E.v.d.M. Smit \\ University of Stellenbosch Business School \\ PO Box 610, Bellville 7535, Republic of South Africa
}

\author{
A. Buijs \\ Utrecht School of Economics, University of Utrecht, \\ Janskerkhof 12, 3512 BL Utrecht, The Netherlands
}

Received October 2008

\begin{abstract}
Given growing interest in the phenomenon of responsible investing (RI) in South Africa, this study set out to identify and empirically evaluate the most pertinent drivers, barriers and enablers of RI locally. Telephone interviews were conducted with a sample of pension funds, asset managers and advisory service providers during 2007. All three groups of respondents viewed fiduciary responsibility as one of the most important barriers to RI in South Africa. More legislation/regulation and evidence for increased risk-adjusted returns from local RIs were identified as key drivers of RI in South Africa, whereas the two most important enablers were seen as mainstream RI benchmarks and co-operative initiatives.
\end{abstract}

*To whom all correspondence should be addressed.

\section{Introduction}

"There are three steps in the revelation of any truth: in the first it is ridiculed; in the second, resisted; in the third it is considered self-evident."

This statement by German philosopher Arthur Schopenhauer (1788-1860) is particularly apt in the light of increasing calls from a new generation of investors, socalled responsible investors, to integrate environmental, social and corporate governance (ESG) considerations into investment decisions and ownership practices. Although many investors still question the rationale and effectiveness of such an investment strategy, empirical evidence shows that responsible investment (RI) in developed economies is gradually moving from a fringe investment strategy to a mainstream consideration (Knoll, 2002: 681; Schueth, 2003: 189).

A report by the US Social Investment Forum for example shows that $\$ 2.29$ trillion or nearly one out of every ten dollars under professional management in the United States of America (USA) was invested on the basis of ethical or ESG criteria in 2005 (Mitchell \& Larson, 2006: 2). This statistic represents a 260 percent increase in RI in the USA over a ten year period. Outside the USA, the most rapid growth in RI has occurred in the United Kingdom, the Netherlands and Sweden (Guay, Doh \& Sinclair, 2004: 126).

In South Africa RI has not experienced the same growth as that observed in the international investment sector. In 2006 
RI funds represented less than one percent of all assets under professional management in the country (Alexander Forbes Asset Consultants Targeted Development Investment Vehicles Manager Watch Survey September 2006, 2006: 1).

It is likely that this percentage has increased somewhat since 2006, driven largely by the commitment of the country's largest pension fund (the Government Employee Pension Fund) to the United Nations' Principles for Responsible Investment (see http://www.unpri.org). Nonetheless, RI remains a niche investment strategy on the periphery of mainstream practices in South Africa.

Given the important contribution that RI has made and can continue to make to the socio-economic development of South Africa, it is necessary to consider why the growth of RI remains limited and what might be done to change this. With this in mind, the purpose of this paper was two-fold:
- $\quad$ Firstly, to identify and describe the possible barriers, drivers and enablers of RI in South Africa (and indeed in general); and

- Secondly, to empirically evaluate the views of the South African investment community on the importance of these theoretical barriers, drivers and enablers.

\section{Barriers, drivers and enablers of RI in South Africa}

An extensive review of the RI literature suggests that the barriers, drivers and enablers listed in could be at play in the South African RI sector. While it is possible that a number of variables in Table 1 could be subdivided or merged; and in some instances be categorised as barriers or drivers in their corollary state, the three lists together represent a comprehensive view.

Table 1: The barriers, drivers and enablers of RI in South Africa

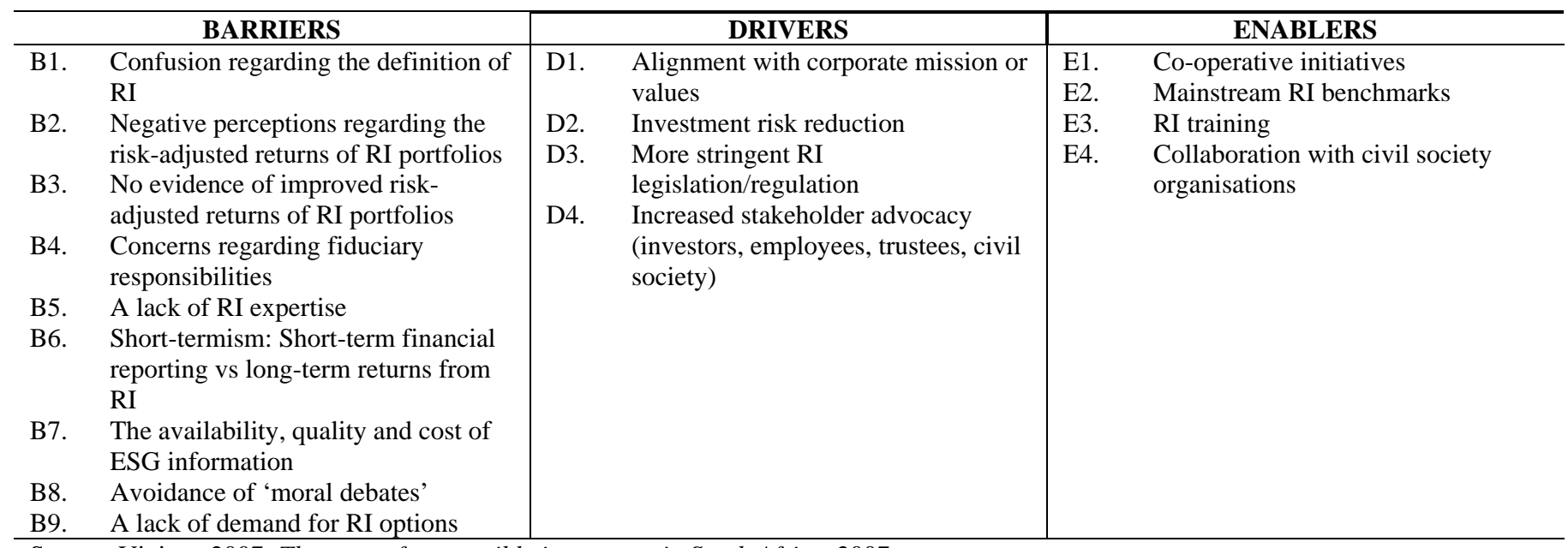

Source: Viviers, 2007; The state of responsible investment in South Africa, 2007

All of the variables listed in Table 1 will now be explored in greater detail.

\section{Barriers of RI in South Africa}

B1. Confusion regarding the definition of RI in South Africa In South Africa stakeholders have, for some time, called for a clarification of the definition of RI, particularly in terms of how it relates to the promotion of broad-based Black Economic Empowerment (BBBEE) (Du Preez, 2005: 39; Leeman, 2005: 9; Wierzycka, 2004; Heese, 2005: 730). It is thus encouraging to note that definitional issues were high on the agenda at the first national RI roundtable held in Cape Town in May 2007 (Responsible investing in South Africa - The way forward, 2007: 3).

B2. Negative perceptions regarding the risk-adjusted returns of RI portfolios

This barrier refers to the perception among many investors and investment professionals that RIs are inferior investments. At least part of this negative perception arises out of portfolio theory which predicts that a narrowing in an investment universe leads to a reduction in the risk-adjusted returns of a portfolio (Schröder, 2007: 331). It is important to note that, in general, this theoretical prediction has not been supported by empirical evidence internationally (Guerard, 1997: 476; Kurtz, 1997: 37; Schröder, 2007: 331) or locally (Viviers, 2007).

B3. No evidence of improved risk-adjusted returns of $R I$ portfolios

Although intuitively not as compelling as the former barrier (B2), it seems likely that a lack of any evidence of improved risk-adjusted returns of local RI portfolios may also contribute to investors' aversion to RI.

\section{B4. Concerns regarding fiduciary responsibilities}

According to a report by the World Economic Forum, new regulations regarding trustees' fiduciary duties have heightened their sensitivity toward risk taking and have encouraged inertia around 'tried and tested' approaches (which often exclude RI) (Mainstreaming responsible investment, 2005: 9). This increasing sensitivity is to some extent offset in a number of jurisdictions by the Freshfields Bruckhaus Deringer (2005) opinion on RI and fiduciary responsibility which generally concluded that there is no 
legal tension between RI and fiduciary responsibilities. Unfortunately, the scope of this report did not include South Africa causing concerns to linger (De Cleene \& Sonnenberg, 2004: 14).

\section{B5. A lack of RI expertise}

A lack of RI expertise among investment analysts and asset managers has been advanced as one of the crucial variables hindering the growth and development of the RI sector, both locally and internationally (Healing, 2005: 18; Heese, 2005: 733; Mainstreaming responsible investment, 2005: 2).

\section{B6. Short-termism: Short-term financial reporting vs long-} term returns from $R I$

It is a widely held view that the disparity between financial reporting, which is generally short-term, and the period over which RI is likely to yield returns, which is mainly in the long-term, represents a significant barrier to RI (Mackenzie, 2006: 37; Mainstreaming Responsible Investment, 2005: 25). South Africa is no exception. Du Preez (2005: 38) states that South African asset managers often take a shortterm view of investment performance and do not appear to “...appreciate the fact that, unless there are fundamental changes to the local economy, all retirement income is at risk". Leeman (2003) however argues that there are very few incentives for local pension fund trustees and institutional asset managers to behave differently.

\section{B7. The availability, quality and cost of ESG information}

The demand for RIs depends, to a large extent, on the availability, quality and cost of ESG information available to investors. It has been argued that the increasing number of RI research agencies and consultancies internationally have played a positive role in stimulating RI growth globally (Schueth, 2003: 192; McGeer, 2004: 7). This has however not been the case in South Africa. While there has been notable improvements in the triple bottom line reporting by large listed South African companies (Visser, 2005:29; McNulty, 2006: 128), it would appear that the conversion of this into a comprehensible form by RI research agencies and consultancies may be lacking (De Cleene \& Sonnenberg, 2004: 7).

\section{B8. Avoidance of 'moral debates'}

Another barrier to growing the local RI sector deals with investors' avoidance of what can be termed a 'moral debate'. In this regard many investors do not wish to get involved in discussions regarding the ethical nature of investing in companies associated with the production and/or sale of products such as alcohol, tobacco, weapons and gambling. Clearly this view of the scope of RI as being limited to negative (exclusionary) screens is technically erroneous. Indeed some authors have gone so far as to exclude negative ethical screens from the RI toolkit focusing rather on enhanced analytics and shareholder activism (Sullivan \& Mackenzie, 2006: 14). Nonetheless, this has been viewed as a potential barrier to the further uptake of RI in South Africa.

\section{B9. A lack of demand for RI options}

On one level, a lack of demand for RIs may be viewed as a consequence of many of the barriers already discussed, rather than a driver in its own right. However, in the context of investment as a complex value chain, it may be considered as a driver in its own right. This would be particularly the case amongst asset managers and advisory service providers who are likely to structure their activities to service specific requirements from their retail and institutional clients.

\section{Drivers of RI in South Africa}

\section{D1. Alignment with corporate mission or values}

Even within the hard-line world-view inspired by economists such as Milton Friedman where the goal of any business endeavour is seen as the maximisation of profits, mention is made of 'the rules of the game'. Inevitably such rules form the basis of corporate value systems. Likewise, within the specific business sphere of institutional investment, it is possible that value systems may influence investment decisions and indeed drive RI (Dembinski, Bovin, Dommen \& Monnet, 2003: 203).

\section{D2. Investment risk reduction}

Proponents of RI have long argued that ESG issues may represent financially material sources of business risk (Mainstreaming responsible investment, 2005: 15; Show me the money, 2006: 1), and that RI represents the only effective way of managing this risk. While empirical evidence in this regard has proved inconclusive (prompting Kurtz (1997: 37) to propose that there is no net effect), the logic in the argument is compelling, and as such this may indeed represent an important driver of RI.

\section{D3. More stringent legislation/regulation}

It is widely agreed that amendments to pension fund legislation have been one of the most influential forces driving RI internationally (Mansley, 2000: 1; Schwartz 2003: 197; Sparkes \& Cowton, 2004: 50). Such amendments have taken two forms: RI policy disclosure requirements or prescribed asset allocation. In South Africa the discussion has largely focused on the latter (Heese, 2005: 733; Rose, 2004a: 15; Rose, 2004b:2; Strong investment case for SRI, 2005: 58; Wierzycka, 2004, 2005). To date, this discussion has not yet been converted into any legislation, although the South African Treasury Department has published a discussion document proposing that local pension funds be allowed to invest up to a maximum of ten percent in socially desirable investments (Du Preez, 2005: 37).

Beyond this discussion on pension fund legislation, there is also a draft regulatory instrument associated with the country's BBBEE programme that could drive RI in principle. The Financial Sector Charter in particular has given significant impetus to the local RI market committing its signatories to mobilising considerable resources for targeted investments and shareholder activism (Leeman, 2005: 9).

\section{D4. Increased stakeholder advocacy}

Stakeholder advocacy (or pressure) is a very broad driver and one which could be split into a number of elements, the most obvious being various stakeholder groupings. These could include investors (in which case reference is made to shareholder activism), employees and civil society. There is certainly evidence of pressure emanating from South 
African employees and civil society through trade unions and NGOs (Segal, 1997; Seeds of new asset management, 2002: 18; Claasen, 2003: 14). From an investor perspective, this pressure is evident from the growth of local Shari'ah (Islamic law) compliant funds and RI funds which promote socio-economic development (Cameron, 2003: 21).

\section{Enablers of RI in South Africa}

Alongside the above-mentioned drivers, the enablers identified could substantially contribute to the sustained growth of RI by helping to overcome some of the barriers described earlier.

\section{E1. Co-operative initiatives}

The sharing of costs associated with implementing RI practices through co-operative initiatives may well enable more widespread participation in RI by overcoming barrier B7 (The availability, quality and cost of ESG information). Possibly the most notable example of this type of activity internationally is the Enhanced Analytics Initiative which is an international collaboration between asset owners and asset managers (see http://www.enhancedanalytics.com). The aim of the initiative is to promote better investment research, in particular by taking exogenous financial issues into account.

\section{E2. Mainstream RI benchmarks}

Although it has been argued that assessing investment performance in relative rather than absolute terms may in fact undermine RI practices (Mckenzie, 2006: 20), the practice is deeply embedded in the investment community. The development of appropriate benchmarks against which to evaluate the performance of RIs may thus be considered a key enabler of the RI movement. Indeed, the development of international stock market indices dealing with ethical and ESG issues have not only led to a greater awareness of RI but have also provided a useful framework for RI funds to either track or benchmark their performance against (Sauer, 1997: 137; Hussein \& Omran, 2005: 110).

Examples include the Dow Jones Sustainability and Islamic indices, the FTSE4GOOD indices and the KLD indices (including the well-known Domini 400 Social Index). Locally, the FTSE/JSE SRI index was launched in 2004. The development of these benchmarks also provided a means to empirically challenge the perceived barriers B2 and B3 (both relating to risk-adjusted returns) above (Schröder, 2007: 331).

\section{E3. RI training}

A shortage of RI expertise (barrier B5) has been recognised as a possible barrier to the growth of RI both locally and internationally, and could be addressed by means of focussed RI training programmes.

\section{E4. Collaboration with civil society organisations}

Partnerships and collaboration with civil society organisations represent another potential mechanism whereby some of the costs associated with implementation of RI may be shared. Such collaboration can provide potential responsible investors with a very valuable RI 'radar system' to detect emerging ESG issues. Furthermore, formal collaboration can yield key research outputs. Arguably the highest profile of such collaboration is the United Nations' Principles for Responsible Investment which is a partnership between the United Nations and a number of the world's largest institutional investors. The collaboration led to the development an investor framework for the integration of ESG issues in investment decisionmaking and ownership practices.

Having identified the theoretically important barriers, drivers and enablers of RI in South Africa, the perspectives of the institutional investment community with respect to these variables were investigated.

\section{Research design and methodology}

\section{The Survey Sample}

The survey targeted pension funds, asset managers as well as the consultants, advisors and analysts that provide advisory services to these two groups (collectively referred to as advisory service providers in the rest of this article).

The pension funds targeted were a selection of the largest funds in South Africa as listed by Financial Services Board (http://www fsb.co.za) within the following sectors: resources, financial services, retail, communications and high tech, as well as a number of the largest public sector funds and collective industry funds. As indicated in Table 2, a total of 35 funds were approached and of these 32 were telephonically interviewed. These 32 funds held assets under management of ZAR 975 billion. In all instances either the principal officer of the fund, or a person delegated by the principal officer acted as the respondent.

Table 2: The sample

\begin{tabular}{l|c|c|c|c}
\hline & Target & Successful & $\begin{array}{c}\text { \% } \\
\text { Success }\end{array}$ & $\begin{array}{l}\text { Assets under } \\
\text { management }\end{array}$ \\
\hline $\begin{array}{l}\text { Pension } \\
\text { Funds }\end{array}$ & 35 & 32 & $91,4 \%$ & $\begin{array}{l}\text { ZAR 975 } \\
\text { billion }\end{array}$ \\
\hline $\begin{array}{l}\text { Asset } \\
\text { Managers }\end{array}$ & 22 & 19 & $86,3 \%$ & $\begin{array}{l}\text { ZAR 2 320 } \\
\text { billion }\end{array}$ \\
\hline $\begin{array}{l}\text { Advisory } \\
\text { service } \\
\text { providers }\end{array}$ & 15 & 11 & $73,3 \%$ & NA \\
\hline
\end{tabular}

In terms of asset managers, all listed members of the Investment Management Association of South Africa were approached (see http://www.imasa.co.za). In total 22 asset management companies were approached and of these, 19 were interviewed. These reported assets under management of ZAR 2320 billion. Within this group interviews were conducted with the chief investment officer or a person delegated by the chief investment officer. Finally, the survey targeted a sample of 15 advisory service providers and was successful in interviewing 11 . Within this group, chief operating officers or heads of research were targeted as respondents.

The few non-participants (three pension funds, three asset managers, and four advisory service providers) were a combination of institutions that declined outright or institutions that were abandoned after at least 10 attempts to contact an appropriate person failed. Finally, in order to secure frank and honest responses, rather than responses 
aimed at managing reputation, all interviews were protected by a confidentiality agreement which prevented releasing any data linking a company, fund or the person interviewed directly to any outcome.

\section{Survey Questions}

As stated, the survey was carried out to canvas information on the following three basic questions:

- What are the barriers to RI in South Africa?;

- What would drive the pursuance of RI locally?; and

- What would enable the pursuance of RI in South Africa?

Within each of these three broad categories, the respondents were presented with a list of barriers, drivers and enablers covering those set out in Table 1 . Thus, the specific questions which were asked were:

1. Do you consider the following barriers to pursuing RI in South Africa to be "Very Important", "Somewhat Important" or "Not Important"?

- $\quad$ Evidence for reduced risk-adjusted returns from RI portfolios (B2)

- $\quad$ No evidence for improved risk-adjusted returns from RI portfolios (B3)

- $\quad$ Fiduciary responsibility (B4)

- $\quad$ A lack of RI expertise (B5)

- $\quad$ Short-termism: short-term financial reporting versus expected long term returns from RI (B6)

- $\quad$ Lack of adequate information to evaluate investment target ESG related performance (B7 a)

- $\quad$ Too costly to implement / interpretive costs too high (B7 b)

- $\quad$ Avoidance of 'moral debates' (B8)

- $\quad$ Lack of demand for RI options (B9)

2. Would you consider the following variables to be "Very Important", "Somewhat Important" or "Not Important" in driving you to offer RI options?

- $\quad$ Alignment with corporate mission or beliefs (D1)

- $\quad$ Investment risk reduction (D2)

- $\quad$ More stringent legislation/regulation (D3)

- $\quad$ Pressure from employees (or trustees in the case of pension funds) (D4 a)
- $\quad$ Pressure from civil society groups (D4 b)

- $\quad$ Pressure from investors (D4 c, corollary of B9)

- $\quad$ Evidence that RI will increase risk-adjusted returns (corollary of B2)

3. Would you consider the following enablers to be "Very Valuable", "Somewhat Valuable", or "Not Valuable" for your institutions in pursuing RI activities?

- $\quad$ Co-operative initiatives (E1)

- $\quad$ Mainstream RI benchmarks (E2)

- $\quad$ RI training (E3)

- $\quad$ Collaboration with civil society organisations (E4)

Besides some grammatical adjustments to the barriers, drivers and enablers as listed in Table 1, the following minor modifications were made:

- $\quad$ Barrier B1 (Confusion regarding the definition of RI) was not considered. This was done because participants were given with a reference definition of RI prior to beginning the interview in order to ensure consistent interpretation of RI for all the subsequent questions. For the purpose of this research RI was defined as investments that incorporate an active consideration of ESG issues into investment decision making and ownership practices.

- $\quad$ Barrier B2 (Negative perceptions regarding the riskadjusted returns of RI portfolios) was re-evaluated in the corollary form as a driver.

- $\quad$ Barrier B7 (The availability, quality and cost of ESG information) was split into B7(a) to evaluate the availability and quality of ESG information and B7(b) to evaluate the cost of interpreting this information.

- $\quad$ Driver D4 (Increased stakeholder advocacy) was split into D4(a) for employees or trustees, D4(b) for civil society and D4(c) for investors.

\section{Empirical findings: barriers of RI in South Africa}

The perceptions of pension fund principal officers regarding barriers to RI in South Africa are presented in Figure 1, ranked from most important to least important based on the percentage of respondents indicating that the barrier was "Very Important".

Looking first at the most important barriers, principal officers of pension funds collectively ranked the lack of adequate information to evaluate ESG performance (B7 a) as the single most important barrier to RI. 


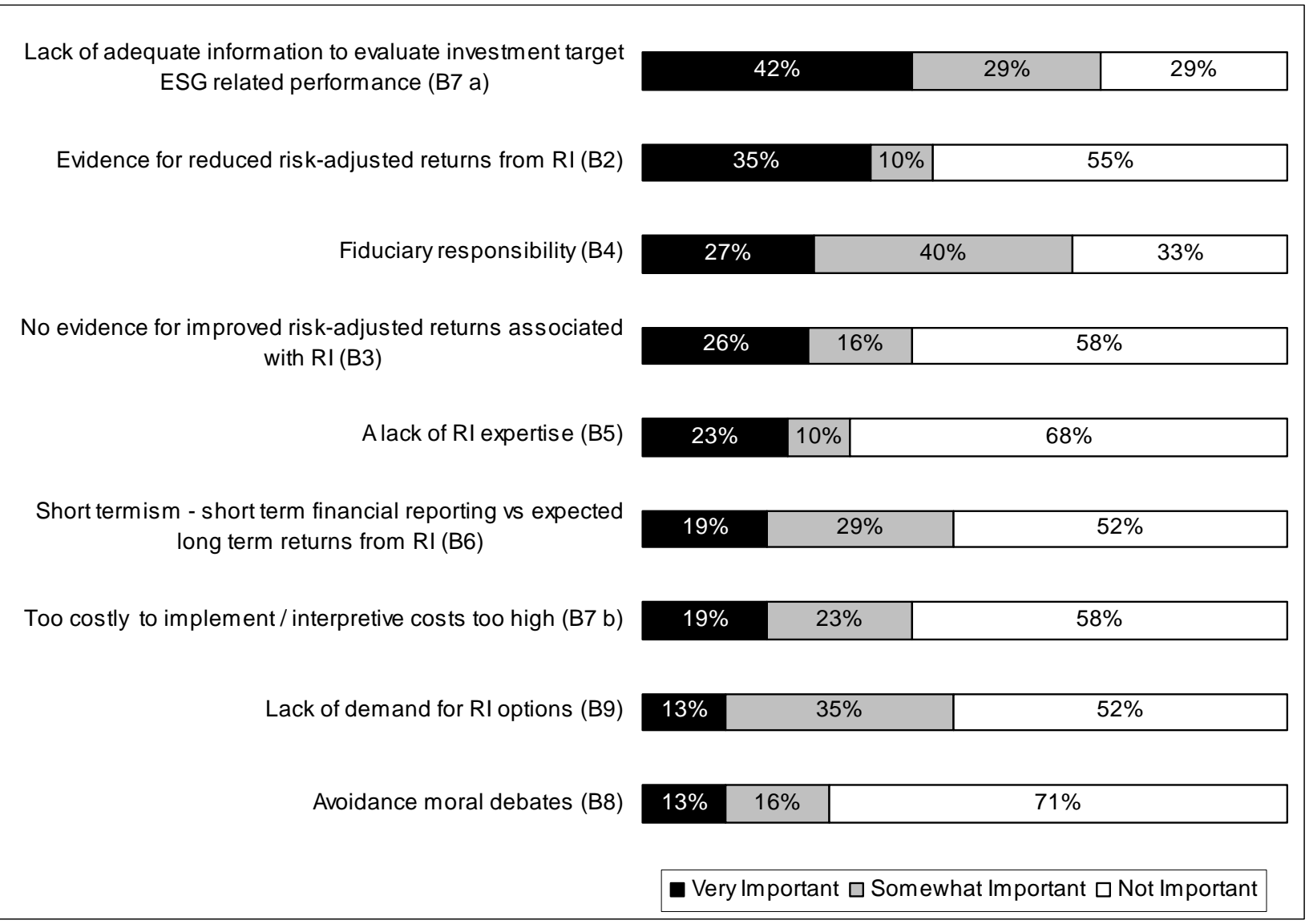

Figure 1: Pension funds - Barriers to RI

The remainder of the 'top-four' barriers was a cluster of three closely related barriers: Evidence for reduced riskadjusted returns (B2); Fiduciary responsibility (B4); and No evidence of improved risk-adjusted returns (B3). All three of these relate to the primary responsibility of pension funds, namely to ensure the financial well-being of their members. Their emphasis is thus on financial performance and the responsibility to ensure that risk-adjusted returns are maximised.

The perceptions of asset managers regarding barriers to RI in South Africa are presented in Figure 2. In contrast with pension funds, asset managers collectively ranked shorttermism (B6) and a lack of demand for RI options (B9) as the two most important barriers to RI. Thereafter, however, they ranked fiduciary responsibility (B4) and evidence for reduced risk-adjusted performance (B2) as key barriers.

The evidence in Figure 3 shows that, as in the case of asset managers, advisory service providers ranked a lack of demand (B9) and short-termism (B6) as the two most important barriers (although the order of the two was switched). Following these two barriers, the group collectively indicated a lack of expertise (B5) as important. Interestingly this barrier was not ranked in the top four by either of the other two groups.

The final 'top four' barrier however was fiduciary responsibility (B4) which was consistent with the perspectives of both the pension funds and the asset managers. In terms of the least important barrier, this group ranked evidence for reduced risk-adjusted performance as the least important barrier.

\section{Empirical findings: drivers of RI in South Africa}

Turning to possible drivers of RI, the rank importance of variables that would stimulate the growth of RI according to local pension fund principal officers is presented in Figure 4. 
Short termism - short term financial reporting vs expected long term returns from RI (B6)

Lack of demand for RI options (B9)

Fiduciary responsibility (B4)

Evidence for reduced risk-adjusted returns from RI (B2)

No evidence for improved risk-adjusted returns associated with RI (B3)

Lack of adequate information to evaluate investment target ESG related performance (B7 a)

Avoidance moral debates (B8)

A lack of RI expertise (B5)

Too costly to implement / interpretive costs too high (B7 b)
$42 \%$

$21 \%$

$37 \%$

$37 \%$

$37 \%$

\begin{tabular}{|l|l|l|}
\hline $21 \%$ & $21 \%$ & $58 \%$ \\
\hline
\end{tabular}

$16 \%$ $58 \%$ $26 \%$

$16 \%$ $16 \%$ $68 \%$

\begin{tabular}{ll|l}
$16 \%$ & $11 \%$ & $74 \%$
\end{tabular}

$5 \%$ $37 \%$ $58 \%$

Very Important $\square$ Somewhat Important $\square$ Not Important

Figure 2: Asset managers - Barriers to RI

Lack of demand for RI options (B9)

Short termism - short term financial reporting vs expected long term returns from $\mathrm{RI}(\mathrm{B} 6)$

$$
\text { A lack of RI expertise (B5) }
$$

Fiduciary responsibility (B4)

Lack of adequate information to evaluate investment target ESG related performance (B7 a)

Too costly to implement / interpretive costs too high (B7 b)

No evidence for improved risk-adjusted returns associated with RI (B3)

Avoidance moral debates (B8)

Evidence for reduced risk-adjusted returns from RI (B2)

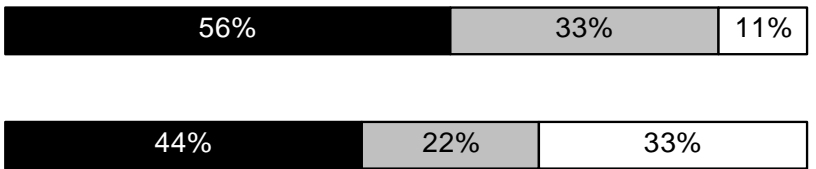

$33 \%$ $22 \%$ $44 \%$

$22 \%$ $33 \%$ $44 \%$

$22 \%$ $33 \%$ $44 \%$

$22 \%$ $33 \%$ $44 \%$

\begin{tabular}{|l|l|l}
\hline $11 \%$ & $22 \%$ & $67 \%$
\end{tabular}

$11 \% \quad 11 \%$ $78 \%$

Very Important $\square$ Somewhat Important $\square$ Not Important

Figure 3: Advisory service providers - Barriers to RI 


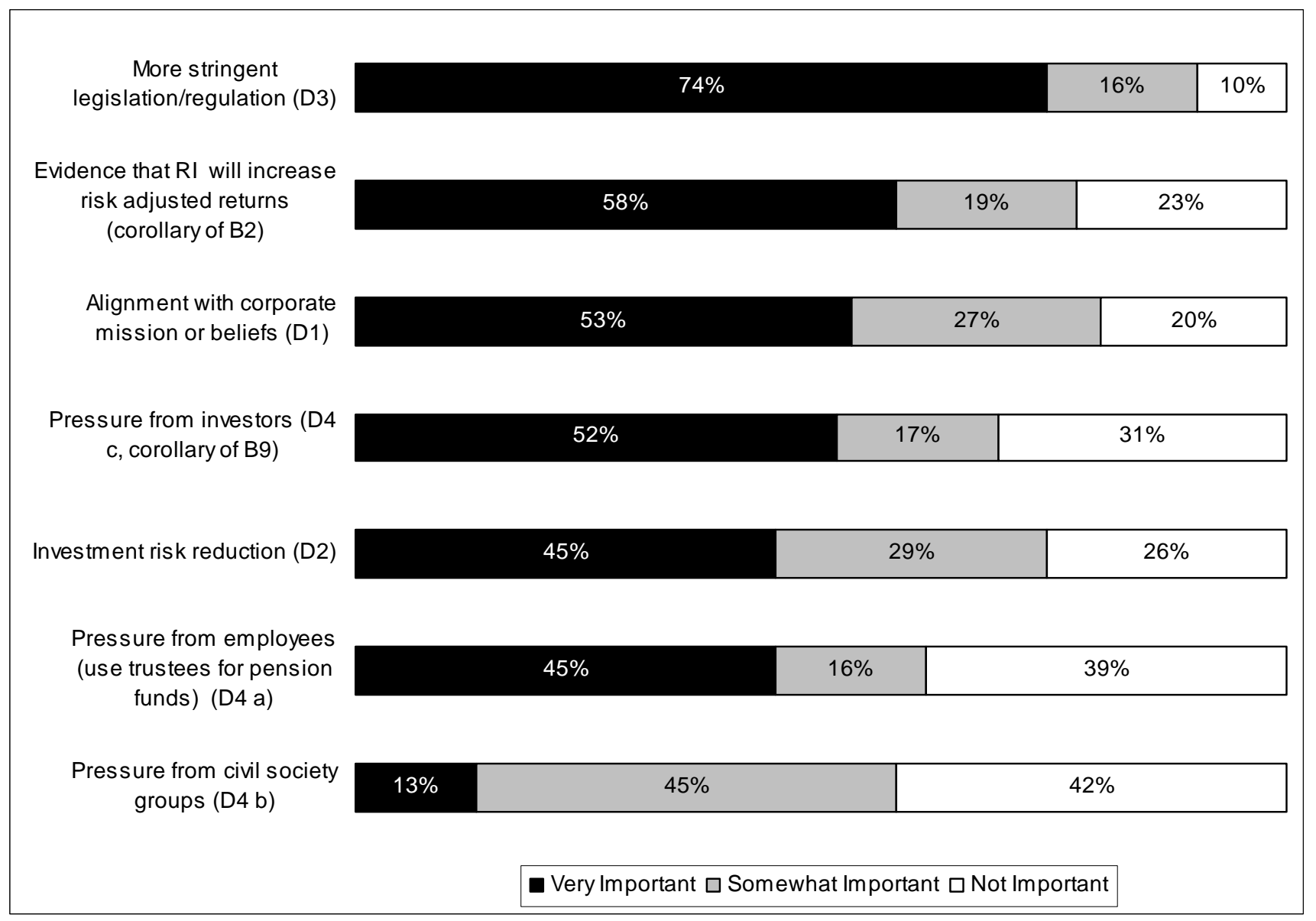

Figure 4: Pension funds - Drivers of RI

At the top of the list of variables that would drive RI amongst pension funds were more stringent legislation/regulation (D3) and evidence that RI would increase risk-adjusted returns (corollary of B2).

The ranking of variables that would drive RI according to asset managers is presented in Figure 5. This group also indicated that evidence of RI resulting in improved riskadjusted returns (corollary of B2) and more stringent legislation/regulation (D3) would both be important drivers of RI (ranked $1^{\text {st }}$ and $3^{\text {rd }}$ respectively). In addition this group indicated that increasing pressure from investors (D4 c) (essentially increasing demand) would also be a prominent driver.

As indicated in Figure 6, advisory service providers also indicated that more stringent legislation/regulation (D3) would be an important driver of RI in South Africa (ranked $\left.2^{\text {nd }}\right)$. As in the case of asset managers this group also viewed increasing pressure from investors (D4 c) (demand) as an important potential driver.

\section{Empirical findings: enablers of RI in South Africa}

Assuming then, that institutional investors can be 'driven' or encouraged to participate in RI, what would be considered useful enablers? The perspective of the local pension fund principal officers regarding the general set of enablers presented to them is illustrated in Figure 7.

Not surprisingly, all of the enablers presented were considered by most of the respondents to be at least "Somewhat Valuable". Mainstream RI benchmarks (E2) were considered to be the most valuable enabler based on the proportion of pension funds that claimed they were "Very Valuable". These results are fairly similar to the opinions expressed by the asset manager group (Figure 8).

Once again the majority of respondents indicated that most of the enablers presented would be "Somewhat Valuable". Furthermore, mainstream RI benchmarks (E2) were considered to be particularly important, although cooperative initiatives (E1) replaced benchmarks as the most valuable enabler. The universal value of mainstream RI benchmarks (E2) was confirmed by the advisory service provider group who collectively ranked this variable as the most valuable enabler (Figure 9). 
Evidence that $\mathrm{RI}$ will increase risk adjusted returns (corollary of B2)

\begin{tabular}{|l|l|l|}
\hline $63 \%$ & $26 \%$ & $11 \%$ \\
\hline
\end{tabular}

Pressure from investors (D4 c, corollary of B9)

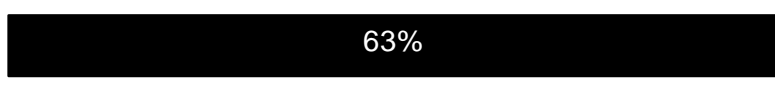

\begin{tabular}{|l|l|}
\hline $21 \%$ & $16 \%$ \\
\hline
\end{tabular}

More stringent legislation/regulation (D3)

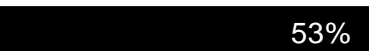
$37 \%$ $11 \%$

Alignment with corporate mission or beliefs (D1)
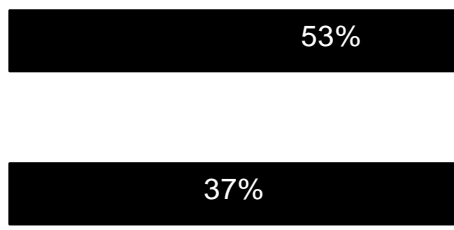

$42 \%$

Pressure from civil society groups (D4 b)

\section{$21 \%$}

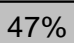

$32 \%$

Pressure from employees (use trustees for pension funds) (D4 a)

\begin{tabular}{|l|l|l|}
\hline $21 \%$ & $26 \%$ & $53 \%$ \\
\hline
\end{tabular}

- Very Important $\square$ Somewhat Important $\square$ Not Important

Figure 5: Asset managers - Drivers of RI

Pressure from investors (D4 c, corollary of B9)

More stringent legislation/regulation (D3)

Alignment with corporate mission or beliefs (D1)

Evidence that RI will increase risk adjusted returns (corollary of B2)

Investment risk reduction (D2)

Pressure from civil society groups (D4 b)

Pressure from employees (use trustees for pension funds) (D4 a)
$78 \%$

$22 \%$

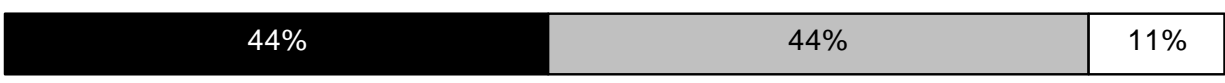

\begin{tabular}{|c|c|c|}
\hline $33 \%$ & $44 \%$ & $22 \%$ \\
\hline
\end{tabular}

\begin{tabular}{|l|l|l|}
\hline $33 \%$ & $44 \%$ & $22 \%$ \\
\hline
\end{tabular}

\begin{tabular}{|l|l|l|}
\hline $33 \%$ & $33 \%$ & $33 \%$ \\
\hline
\end{tabular}




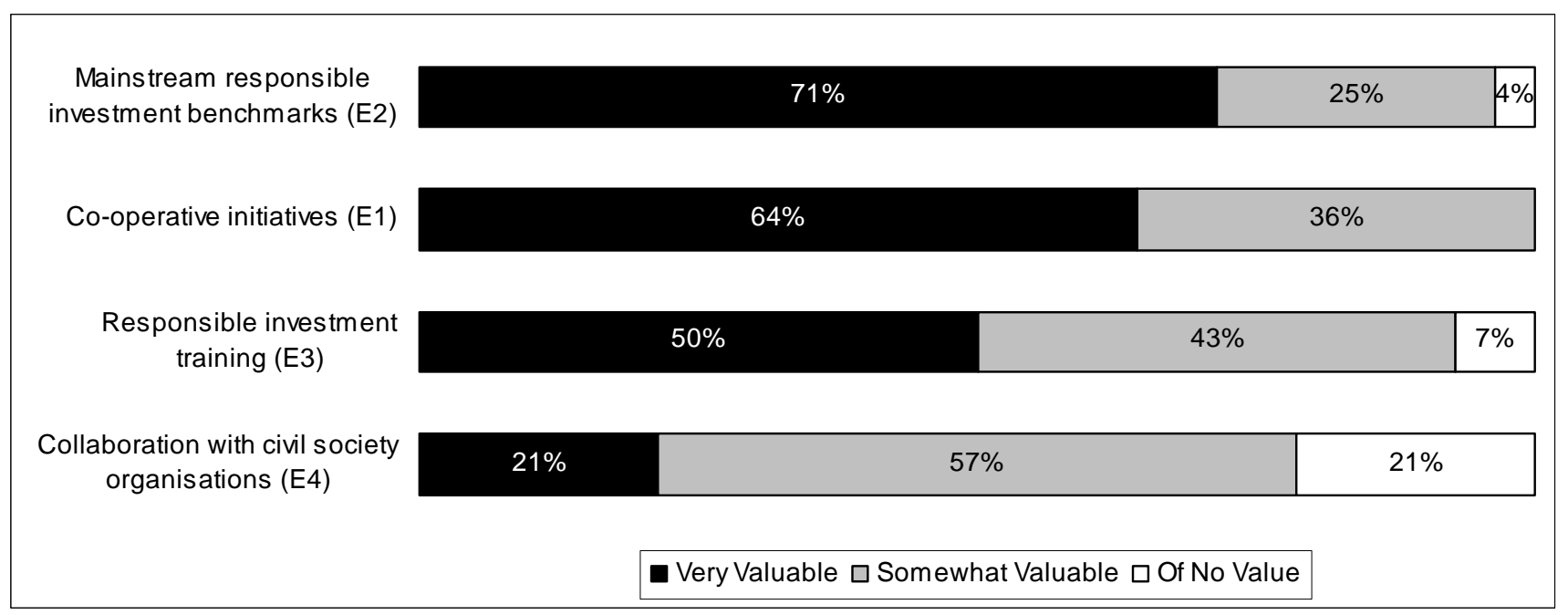

Figure 7: Pension funds - RI enablers

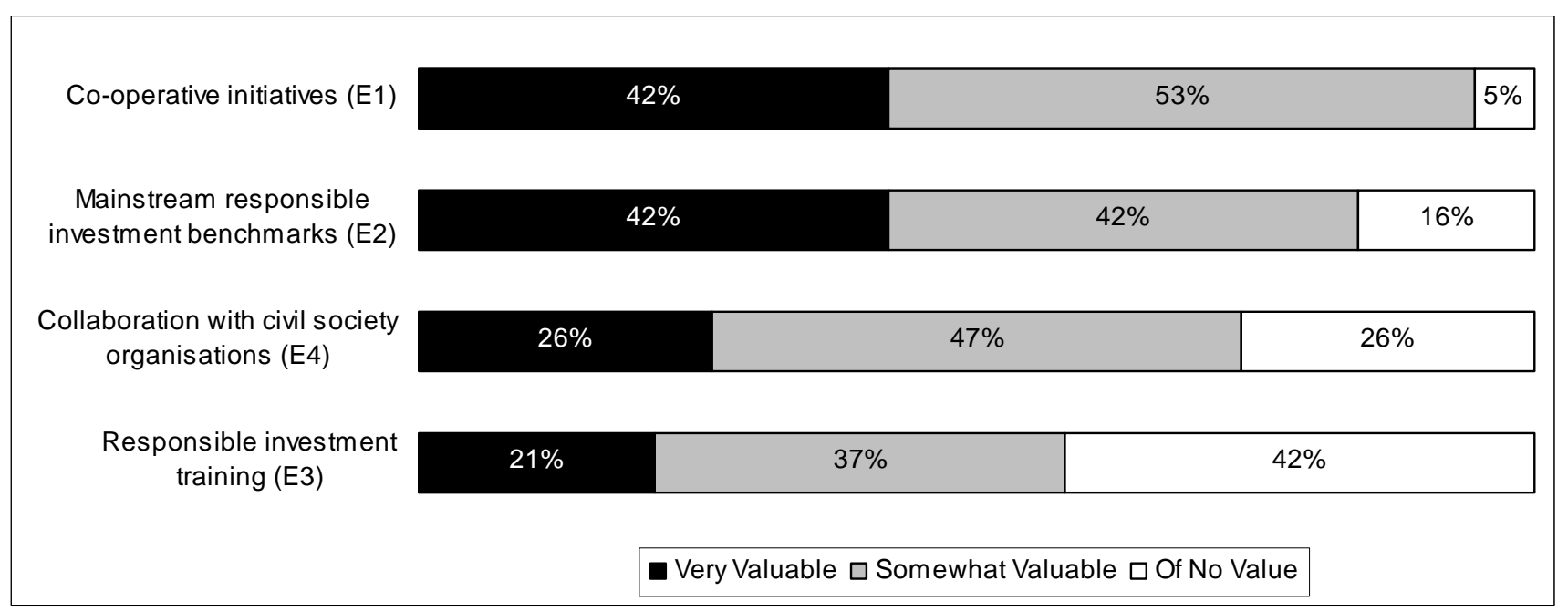

Figure 8: Asset managers - RI enablers

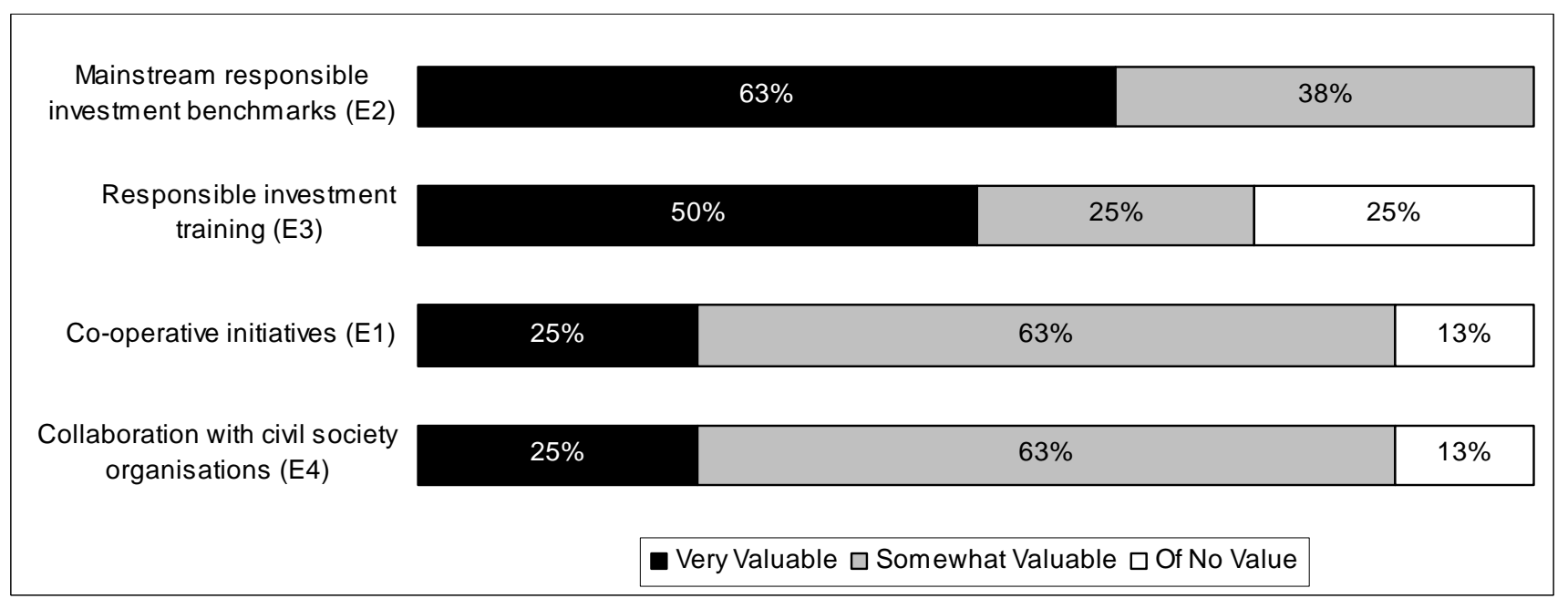

Figure 9: Advisory service providers - RI enablers 
Interestingly, this group ranked collaborative initiatives (E1) near the bottom in terms of value. One possible explanation for this is that collaborative initiatives could potentially remove an opportunity for advisors to sell proprietary RI advisory services.

\section{Conclusions and recommendations}

What then were the overall trends in terms of the barriers to RI in South Africa? Firstly, all three groups viewed fiduciary responsibility as a critical barrier to RI in South Africa. This was particularly pronounced in the case of pension funds where three out of the top four barriers relate to their responsibility of maximising financial returns for members.

Apart from fiduciary responsibility however, there was a clear dichotomy between the pension funds and the two investment professional groups (the asset managers and the advisory service providers). The investment professional groups both saw a lack of demand for RI and short-termism in the industry as key barriers. In terms of lack of demand, the basis for the difference between the groups is not difficult to understand. The professional investment community manages their businesses as businesses and is therefore demand driven. Pension funds are run as technical monopolies (members generally have no choice) and are therefore somewhat less demand driven.

Superficially, the short-termism dichotomy is also easily explained. It is a commonly expressed view that pension funds are inherently long-term in their investment horizon (Mackenzie, 2006:34). However, if it is assumed that pension funds represent a significant component of the customer base of the investment professional groups, and it is noted that as a group, investment professionals appear to be strongly demand-driven, then one ought to ask where the pressure for short-termism within the investment community is coming from?

Part of the answer is surely from within the investment professional sector itself. The entire investment paradigm is based on serial trading and profit taking, and incentive systems are set up to reward short-term performance (Mainstreaming responsible investment, 2005: 25). However, incentive systems do not evolve in a vacuum, and it stands to reason that pressure from pension funds must play a significant role in perpetuating short-termism. This view is supported by the obvious strong emphasis placed on maximising financial returns by pension funds.

In terms of the most important drivers of RI in South Africa, there is a large degree of consistency between all three groups. Across all groups, more stringent legislation/regulation was ranked as a prominent driver. To some extent this finding is to be expected: if a certain behavior is a legal requirement, compliance would not be optional.

Besides simply ranking legislation/regulation as an important driver, ten respondents made specific comments on this driver. Amongst these, the most commonly expressed view was that regulation would be a bad idea.
Strong anti-regulatory views were also identified in the literature review (Rose, 2004b: 2; Wierzycka, 2004, 2005; Heese, 2005: 733).

Should RI legislation become inevitable in South Africa, a preference has been expressed for RI policy disclosure rather than prescribed asset allocation (De Cleene \& Sonnenberg, 2004: viii). Such a legislative approach would have the distinct advantage over formalised 'RI' targets of not further entrenching the myth that RI is necessarily a low return, high risk philanthropic endeavour.

Besides legislation/regulation, all groups expressed the view that evidence for increased risk-adjusted returns from RI would be an important driver. This result is again hardly surprising given the fiduciary responsibility of pension funds, and the very nature of business as a strongly profit driven activity.

Finally, the results here reinforced the view that the investment professionals groups are strongly demand driven. Both investment professional groups ranked pressure from investors as a key driver. Expectations are that more local investors will become engaged shareholders (Bacher, 2004: 4) especially in the light of the recent announcement by the Government Employees Pension Fund that it will use its financial power to “...force corporate South Africa to shape up in areas of good governance, social responsibility and environmental protection" (Cameron, 2006; Bonorchis, 2007).

The two most important enablers of RI locally are seen as mainstream responsible investment benchmarks and cooperative initiatives. It is interesting to note that the only group which viewed RI training as a potential enabler (advisory service providers) was also the only group which indicated a lack of expertise as a barrier to RI.

Based on the findings of this research, it is clear that much remains to be done to encourage RI in South Africa. In essence a re-branding process, which has the support of all major public and private pension funds, the National Treasury, trade unions and professional investment associations, should be undertaken. The process should focus on the negative perceptions regarding the risk-return profile of RI and address the lack of expertise in the local sector.

\section{Acknowledgements}

The authors would like to thank the National Research Foundation (Thuthuka Programme); the Nelson Mandela Metropolitan University; Noah Financial Innovation; and the United Nations Environment Programme Finance Initiative (UNEP FI) for their financial support of this research. Acknowledgement is also given to $\mathrm{Mr}$ S Nicholls of KPMG for his contribution to the research.

\section{References}

Alexander Forbes Asset Consultants Targeted Development Investment Vehicles Manager Watch Survey September 2006. 2006. [online] URL: 
http://www.aforbes.co.za/AfricaFinancial/financial_assetcon s.htm. Accessed 15 October 2006.

Bacher, D. 2004. 'Fondse belê traag in etiese beleggings', Sake Rapport, 12 September: 4.

Bonorchis, R. 2007. 'State fund managers shake up investor activism', Business Day, 18 July, [online] URL: http://www.businessday.co.za/articles/topstories.aspx?ID=B D4A518525. Accessed 18 July 2007.

Cameron, B. 2006. 'State pension fund to turn up heat on corporate SA', Personal Finance, 26 May, [online] URL: http://www.persfin.co.za/index.php?fSectionId=595\&fArticl eId=3264739. . Accessed 29 May 2006.

Cameron, J. 2003. 'Trust fund attracting Muslim money', Citizen, 18 September: 21.

Claasen, L. 2003. 'Anglo, Shell bow to green pressure', Business Day, 29 May: 14.

Dembinski, P.H., Bonvin, J-M., Dommen, E. \& Monnet, FM. 2003. 'The ethical foundations of responsible investment.', Journal of Business Ethics, 48:203-213.

De Cleene, S. \& Sonnenberg, D. 2004. Socially responsible investment in South Africa. $2^{\text {nd }}$ Edition. Johannesburg: African Institute of Corporate Citizenship, pp. 1-49.

Du Preez, L. 2005. 'Investing beyond the bottom line', Personal Finance, 1st Quarter: 32-45.

Freshfields Bruckhaus Deringer. 2005. A legal framework for the integration of environmental, social and governance issues into institutional investment. Genève: UNEP FI, pp. 1-153.

Guay, T., Doh, J.P. \& Sinclair, G. 2004. 'Non-governmental organizations, shareholder activism and socially responsible investments: ethical, strategic and governance implications', Journal of Business Ethics, 52(1): 125-139.

Guerard, J.B. Jr. 1997. 'Is there a cost to being socially responsible in investing?’ Journal of Investing, 6(2): 11-19.

Healing, J. 2005. 'Social investments give great returns', Sunday Times, 29 May: 18.

Heese, K. 2005. 'The development of socially responsible investment in South Africa: experience and evolution of SRI in global markets', Development Southern Africa, 22(5): 729-739.

Hussein, K. \& Omran, M. 2005. 'Ethical investment revisited: evidence from Dow Jones Islamic Indexes', The Journal of Investing, 14(3): 105-124.

Knoll, M.S. 2002. 'Ethical screening in modern financial markets: The conflicting claims underlying socially responsible investment', The Business Lawyer, 57(2): 681726.
Kurtz, L. 1997. 'No effect, or no net effect? Studies on socially responsible investing', Journal of Investing, Winter: $37-49$.

Leeman, M. 2003. 'SRI in South Africa'. Presentation to the Canadian Social Investment Forum. July, Toronto.

Leeman, M. 2005. 'Sifting through socially responsible investment jargon’, Business Report, 8 February: 9.

Mainstreaming Responsible Investment. 2005. Report by the World Economic Forum, January, [online] URL: http://www.weforum.org/pdf/mri.pdf. Accessed 4 January 2006.

Mansley, M. 2000. Socially responsible investment: a guide for pension fund managers. Suffolk, UK: Monitor Press.

Mackenzie, C. 2006. 'The scope for investor action on corporate social and environmental impacts'. In Sullivan, R. \& Mackenzie, C. (eds.) Responsible investment. Sheffield, UK: Greenleaf Publishing, pp. 20 - 38.

McGeer, B. 2004. 'Community banking: bad guys give good-guy fund new luster', American Banker, 169(119): 79.

McNulty, A. 2006. 'Accountability rating', Financial Mail, 27 October: $128-138$.

Mitchell, P. \& Larson, T. 2006. 'Trends report', Social Investment Forum, 24, [online] URL: http://www.socialinvest.org/areas/news/2005Trends.htm. Accessed 1 October 2006.

Petersen, F. 2006. 'Socially responsible investing'. Presentation at the $5^{\text {th }}$ Annual Business Ethics Network Africa Conference, 26 July 2006, Cape Town.

Responsible investing in South Africa - The way forward. 2007. Minutes of the first South African roundtable, 30 May, Cape Town (Available from the authors).

Rose, R. 2004a. 'Funds catch on to social duties', Business Day, 3 September: 15.

Rose, R. 2004b. 'Pension reforms 'threaten social investment’, Business Day, 7 December: 1-2.

Sauer, D.A. 1997. 'The impact of social responsibility screens on investment performance: evidence from the Domini 400 social index and Domini equity mutual fund', Review of Financial Economics, 6(2): 137-150.

Schröder, M. 2007. 'Is there a difference? The performance characteristics of SRI equity indices', Journal of Business Finance \& Accounting, 34(1):331-348.

Schueth, S. 2003. 'Socially responsible investing in the United States’, Journal of Business Ethics, 43(3):189-194.

Schwartz, M.S. 2003. 'The "ethics” of ethical investing', Journal of Business Ethics, 43(3):195-231. 
'Seeds of new asset management'. 2002. Financial Mail Special Report, 168(3): 1-18.

Segal, S. 1997. 'Funds that give the feel-good factor are booming', Financial Mail, [online] URL:http://www myclassguide.com/FM\%20Top\%20100\%2 0Companies\%20-

\%20Social\%20Responsibility\%20Funds htm. Accessed 10 August 2006.

Show me the money: Linking environmental, social and governance issues to company alue. 2006. Geneve: UNEP FI.

Sparkes, R. \& Cowton, C.J. 2004. 'The maturing of socially responsible investments: a review of the developing link with corporate social responsibility', Journal of Business Ethics, 52(1): 45-57.

'Strong investment case for SRI'. 2005. Finance Week, 27 July: 58.

Sullivan, R. \& Mackenzie, C. 2006. 'Introduction'. In Sullivan, R. \& Mackenzie, C. (eds.). Responsible investment. Sheffield, UK: Greenleaf Publishing, pp. 12-19.

Temkin, S. 2003. 'Use shareholders to enforce ethics', Business Day, 24 February: 7.

The state of responsible investment in South Africa. 2007. Noah Chair in Responsible Investment, Centre for Corporate Citizenship, UNISA. [online] URL:http://www.unisa.ac.za/ccc/reports. Accessed 14 December 2007.

Visser, W.A.M. 2005. 'Corporate citizenship in South Africa - a review of progress since democracy', Journal of Corporate Citizenship, (18): 29-38.

Viviers, S. 2007. 'A critical assessment on socially responsible investing in South Africa'. Unpublished doctoral thesis, Nelson Mandela Metropolitan University, Port Elizabeth.

Wierzycka, M. 2004. 'Weighing up pension funds and the social good', Sunday Times Business Times, 16 May, [online] URL:

http://sundaytimes.co.za/2004/05/16/business/money/mone y07.asp. Accessed 18 May 2004.

Wierzycka, M. 2005. 'Examining prescription of socially responsible investments’, Business Report, 15 March, [online] URL:

http://www.busrep.co.za/index.php?fSectionId=564\&fArticl eId=2446716 Accessed 26 July 2005. 